\title{
NENAD MOAČANIN, THE DOYEN OF OTTOMAN STUDIES IN CROATIA
}

\section{by Vjeran Kursar}

Professor Nenad Moačanin was born in Zagreb, Croatia, on March 1, 1949. It seems that family background may have influenced his career choices. His father Fedor Moačanin was a museum curator - director, as well as historian, an expert on the Habsburg military border in Croatia, Vlachs, and the history of Serbs in Croatia. ${ }^{1}$ The Moačanins are a family of Serbian Orthodox Christian origin settled in Zagreb since the beginning of the $20^{\text {th }}$ century, with a long family tradition extending to the late $17^{\text {th }}$ century and the great flight of the Serbs from the Ottoman Empire to the Habsburg territory during the War of the Holy League against the Ottomans (1683-1699). The name of the place of the refuge, Mohács (Croatian Mohač, Turkish Mohaç) in today's Hungary, became the family name - Moačanin, "one from $\mathrm{Mo}(\mathrm{h})$ ač.”

Like his father Fedor, Nenad Moačanin graduated from the Classical Gymnasium in Zagreb, where he, among other subjects, mastered Latin and Ancient Greek languages. In 1972, Moačanin graduated with BA in History from Faculty of Humanities and Social Sciences, University of Zagreb. In order to widen knowledge and obtain adequate linguistic tools for future research, in the following year Moačanin moved to neighbouring Bosnia and Herzegovina, back then another fellow republic in Yugoslav federation, to start his second BA programme at University of Sarajevo. The obvious choice were Oriental Studies, with Turkish language and literature as major (A), Arabic language and literature as minor (B), and Persian as the third subject (C). An ear for languages ran in the family as well.

In addition to the so-called classical Latin and Greek languages, and fluency in the main European languages - above all the trinity of English, French, and German, the father and the son developed interest in and mastery of exotics, too. It seems that only the Second World War prevented Fedor Moačanin from mastering the Oriental studies and Arabic, Persian, and Turkish linguistics. As an ethnic Serb he had to flee the country during the fascist Nazi-alligned Ustaša regime in Croatia in 1941, while his teacher, the Russian emigree Aleksei Olesnicki, the head of the Oriental Collection of Croatian Academy of Sciences and Arts, and the adjunct

\footnotetext{
On Fedor Moačanin see: Ivo Goldstein and Mario Strecha, "Fedor Moačanin (1918-1997)," Radovi Zavoda za hrvatsku povijest 30 (1997): 359-360; Nataša Štefanec, "Fedor Moačanin kao povjesničar Vojne Krajine," in: Fedor Moačanin, Radovi iz povijesti Vojne krajine, ed. by Nataša Štefanec (Zagreb: Srpski kulturno društvo "Prosvjeta," 2016), 9-26.
} 
professor of Oriental languages at the University of Zagreb, died of fear for his life during the Allied bombardment of Zagreb in 1943. Nevertheless, later as the curator of the Judaica collection in the Museum of Arts and Crafts, Fedor Moačanin taught himself Hebrew, instead. The origin of Nenad Moačanin's mother, Neda Moačanin (born Šarčević), from the Slavonian town of Đakovo, may have determined the interest of her son in Ottoman Slavonia.

During 1975 and 1976, Nenad Moačanin was mastering Arabic language in Algeria with the Algerian government's stipend. Spoken Turkish Moačanin was mastering for years on numerous shorter or longer research visits to Ottoman archives and libraries in Turkey.

After graduating from University of Sarajevo in 1979, Moačanin returned to Zagreb to enter the graduate programme of Early Modern History at Faculty of Humanities and Social Studies. During 1980 and 1981 he was in Munich specializing in the fields of Turkish and Ottoman studies at Institut für Geschichte und Kultur des Nahen Ostens sowie für Turkologie. In 1983, he obtained MA with the thesis entitled Administrative Division and the People of the Sandjak of Požega (“Upravna podjela i stanovništvo Požeškog sandžaka”). In 1990, Moačanin graduated with the doctoral dissertation entitled Towns in Turkish Slavonia and Srijem ("Gradovi u turskoj Slavoniji i Srijemu"), under the supervision of Professor Milan Vasić, one of the well renowned Yugoslav Ottomanists of the time. This represented the beginning of the decades-long research of the history of Ottoman Slavonija, which was crowned with three monographs - Požega i Požeština u sklopu Osmanlijskoga carstva (1537.-1691.) [Požega and the Region of Požega within the Framework of the Ottoman Empire (1537-1691)] (Jastrebarsko: Naklada Slap, 1997), Slavonija i Srijem u razdoblju osmanske vladavine [Slavonija and Srijem during the period of the Ottoman rule] (Slavonski Brod: Hrvatski institut za povijest, Podružnica za povijest Slavonije, Srijema i Baranje, 2001), and Town and Country on the Middle Danube (Leiden-Boston: Brill, 2006).

Moačanin started his professional career at Institute for Historical Sciences of Yugoslav Academy of Sciences and Arts (today's Croatian Academy of Sciences and Arts) in Zagreb (1978-1992). In 1992, he joined Department of History of Faculty of Humanities and Social Sciences in Zagreb, beginning as an associate, soon to be promoted to the rank of assistant professor (1993-1998), then associate professor (1998-2002), and eventually professor (2002-2019). Moačanin was a member of Croatian History Programme of Department of History. He served a mandate as the head of the Department and the head of Croatian History Programme. In addition, Moačanin was collaborating with Turkish Studies Programme of the Department of Oriental and Hungarian Studies (today's Department of Hungarian, Turkish and Judaic Studies), where he taught courses "Islamic Civilization" and "Ottoman Palaeography and Diplomatics" from 1994 to 2017. According to Pro- 
fessor Ekrem Čaušević, the founder of Turkish Studies Programme (in 1994), and its long-term head, "the foundation of Turkish Studies Programme was above all the idea of Nenad Moačanin, and therefore he should be remembered as the conceptual originator of this programme."

The link between history and Turkish studies that Professor Moačanin embodied through his educational and scientific work, that is, a combination of historical science with a strong linguistic component, which is essential for the field of Ottoman studies, proved to be a sound foundation for the future of Ottoman studies in Zagreb, too. Today, two decades after the establishment of Turkish Studies programme, Zagreb figures as a regional centre for Turkish and Ottoman studies. Zagreb was the venue for several international congresses organized by the Ottomanist team. In 2008, CIEPO 18 (Comité International d'Études Pré-Ottomanes et Ottomanes) conference attended by 160 presenters from 18 countries was organized in Zagreb, in cooperation with Turkish Studies Programme and Professor Ekrem Čaušević. The proceedings of the conference were published as two separate volumes in Berlin and Edirne edited by Nenad Moačanin, Ekrem Čaušević and Vjeran Kursar. ${ }^{2}$ A workshop entitled "The Latest Edition of Evliya Çelebi's Seyahatname: The Account of New Insights" was organized at Faculty of Humanities and Social Sciences in Zagreb in 2016 as part of the project "Evliya Chelebi and Croats - New Perspectives" led by Professor Moačanin and financed by Croatian Endowment for Science. The workshop was attended by leading specialists in the field, including Robert Dankoff, Hakan Karateke, Jean-Louis Bacqué-Grammont, Nuran and Semih Tezcan, and Slobodan Ilić, among others. Proceedings of the workshop, edited by Vjeran Kursar, Nenad Moačanin and Kornelija Jurin Starčević, were published in Zagreb in 2021. ${ }^{3}$ Another major Ottomanist conference, International Congress of Ottoman Social and Economic History (ICOSEH), locally organized by Vjeran Kursar and Nenad Moačanin, is re-scheduled for July 2022 at Faculty of Humanities and Social Sciences, and will be attended by 120 Ottomanists from around the world.

Nenad Moačanin gave numerous invited lectures at international educational and research centres, such as Ankara University, Middle East Technical University in Ankara, University of California - Riverside, American Research Institute in Turkey (ARIT) in Istanbul, Institute for Oriental Studies of University of Vienna,

2 Ekrem Čaušević, Nenad Moačanin, Vjeran Kursar, eds., Perspectives on Ottoman Studies (Papers from the 18th CIEPO) (Berlin: Lit Verlag 2010); Ekrem Caušević, Nenad Moačanin, Vjeran Kursar, eds., Osmanlı Sanatı, Mimarisi ve Edebiyatına Bakış, 18. CIEPO Sempozyumu (Edirne: Trakya Üniversitesi, 2011).

3 Vjeran Kursar, Nenad Moačanin, Kornelija Jurin Starčević, eds., Evliya Çelebi in the Borderlands: New Insights and Novel Approaches to the Seyahatname (Western Balkans and Iran Sections) (Zagreb: Srednja Europa, 2021). 
and Central European University in Budapest. During spring semester of 2002, he gave a series of lectures on Croatian history at Department of History of Faculty of Humanities and Social Sciences of University of Ljubljana.

Nenad Moačanin was the project manager of two scientific projects financed by Croatian Ministry of Science, Education and Sports: "Croato-Turcica" (19972006) and "Turkish Sources for Demographic Picture of Croatian Area and surroundings" (2007-2013). He was also the project manager of the project "Evliya Chelebi and Croats: New Perspectives" (2015-2017), financed by Croatian Endowment for Science.

Professor Moačanin is without doubt the most important Croatian Ottomanist. He continues in the footsteps of his predecessors like Ćiro Truhelka or Aleksej Olesnicki, who earlier attempted to establish "Oriental" or Turkish Studies at University of Zagreb. Moačanin's achievements in the fields of research and education in Croatia are unparalleled, so it is possible to say that he is the founder of modern Croatian Ottoman studies.

The most important Moačanin's work is the book Town and Country on the Middle Danube published by Brill, Leiden, as the 35th volume of the series "The Ottoman Empire and its Heritage" in 2005. This work represents the continuation of Moačanin's research that began in the book Slavonia and Srijem in the Period of Ottoman Rule (Slavonija i Srijem u razdoblju osmanske vladavine, 2001). Primarily based on the study of tax registers, in this pioneering book Moačanin analyses socio-economic situation in towns and villages in Ottoman Slavonia and Srijem. The Moačanin's book Turkish Croatia (Turska Hrvatska, 1999) represents the first and so far the fullest attempt at summarizing the history of Croatian lands under the Ottoman rule. It critically analyses important topics such as Islamization of local population, and demographic changes generated by immigration of nomadic and seminomadic Vlach population, which enjoyed special privileged status. Another revised and enlarged synthesis of the Ottoman period of Croatian history Moačanin published in the form of the textbook entitled Croatian-Slavonian Military Border and Croats under the Rule of the Ottoman Empire in the Early Modern Period (Hrvatsko-slavonska Vojna krajina i Hrvati pod vlaš́u Osmanskoga Carstva u ranome novom vijeku (Zagreb: Leikam, 2007, with Željko Holjevac). Back in 1997, Moačanin published his first book Požega and the Region of Požega within the Framework of the Ottoman Empire (Požega i Požestina u sklopu Osmanlijskoga carstva (1537.-1691.)). Based on analysis of Ottoman survey records, Moačanin examined economic and demographic situation in the region of Požega, i.e., the kadi district (kadilik) of Požega. A very important addition to the study was the translation of four general tax registers for 1540,1545, 1561 and 1579, which was the first and still the most exhaustive translation of Ottoman sources into Croatian language. One of the Moačanin's most important contributions to the field was 
the analysis of the correlation between taxes and demography. In addition to the above-mentioned titles, his other important studies are Islamization of Peasantry in Bosnia from the $15^{\text {th }}$ to the $17^{\text {th }}$ Centuries: Demistification (Islamizacija seljastva u Bosni od 15. do 17. stoljeća: demistifikacija) ${ }^{4}$ and Population of the Bosnian Eyalet in the $18^{\text {th }}$ Century according to the Poll-Tax Registers (Stanovnistvo Bosanskog ejaleta u 18. stoljeciu prema popisima glavarine). ${ }^{5}$ In addition to studies of socio-economic nature, Moačanin wrote other important works based on sources of different character, such as the travelogue of the famous Ottoman traveller Evliya Çelebi 'New' Evliya Çelebi: the autograph of the Travelogue, in co-authorship with Kornelija Jurin Starčević, ('Novi' Evlija Celebi: autograf 'Putopisa), ${ }^{6}$ Livno and the Livno Region in the Travelogue of Evliya Çelebi and Turkish Archival Sources of the $17^{\text {th }}$ century (Livno i livanjski kraj u Putopisu Evlije Čelebija i u turskim arhivskim izvorima 17. stoljeća), ${ }^{7}$ or, the project of the construction of the famous bridge of Suleyman II the Magnificent in Osijek, Cisr-i kebir-i Ösek (Veliki osječki most). ${ }^{8}$

As a talented polyglot, who in addition to the Ottomanist trinity of Turkish, Arabic and Persian, knows well major European languages, in addition to Latin and ancient Greek, as well as, somewhat surprisingly, basic Hungarian, Moačanin translated several important books from German and French into Croatian. ${ }^{9}$ Those include a long-time Ottoman history textbook - Josef Matuz's Das Osmanische Reich (Osmansko Carstvo (Zagreb: Školska knjiga, 1992)), Walter Beltz’s Sehnsucht nach dem Paradies - Mythologie des Korans (Mitologija Kur'ana: čežnja za rajem (Zagreb, GZH, 1982)), and Maxime Rodinson's classic Marxisme et monde musulman (Marksizam i muslimanski svijet (Zagreb, Globus, 1988)).

Professor Moačanin is a well-known Ottomanist with over 130 international and local publications in English, French, Italian, German, Turkish, Hungarian and Croatian, and one of the greatest experts on the Ottoman Balkans and Central Europe. In addition to participation in almost all relevant Ottomanist gatherings for almost five decades, Moačanin is the member of the bodies of two leading Ottomanist associations: the Governing Directorate of Comité International d'Études Pré-Ottomanes et Ottomanes (CIEPO), and the Executive

4 In Zbornik Mirjane Gross (Zagreb: Zavod za hrvatsku povijest Filozofskog fakulteta Sveučilišta u Zagrebu, 1999), 53-63.

5 In Rad Hrvatske akademije znanosti i umjetnosti. Razred za društvene znanosti $50=516$ (2013): 93-119.

6 In Književna Smotra 46, 173 (3) (2014): 77-90.

7 In CLEUNA 3 (2019): 199-207.

8 (Zagreb - Osijek: HAZU, 2014), 91-111; English edition in: Muhammet Savaş Kafkasyalı (ed.), Balkanlarda İslam, vol. 3 (Ankara: Türk İşbirliği ve Koordinasyon Ajansı (TİKA), 2016), 466-479.

9 Moačanin learned Hungarian with the support of his wife, late Klara Gönc Moačanin, an ethnic Hungarian, and Indologist. 
Committee of International Association of Ottoman Social and Economic History (IAOSEH). In 2013, Moačanin received a special recognition from Turkey and became the honorary member of Turkish Historical Society (Türk Tarih Kurumu). Moačanin is the corresponding member of Croatian Academy of Sciences and Arts (Social Sciences Section) since 2012. In 2019, he initiated the establishment of the Academia's Scientific Committee for Research of Relations between Croatia and the European Southeast in Historical Perspective, and was elected its president. Moačanin is also the member of Society for Croatian History (Društvo za hrvatsku povjesnicu), Matrix Croatica (Matica hrvatska), and C. G. Jung Institute for Analytical Psychology in New York. Perhaps this last membership indicates best the wideness of his interests, which do not end at the confines of Ottoman socioeconomic history, but extend into fields of culture and religion in Islamic world in general, and, furthermore, enter into some unexpected areas such as Jungian analytical psychology.

When it comes to hobbies and free time activities, his passion for jazz has to be mentioned in the first place, along with his astonishing collection and wide knowledge about the genre. Nenad Moačanin is also well known in local weight-lifting circles, a sport in which he excelled enough to actively compete in local tournaments in the 1970s and early 1980s. Later he continued to practise the sport recreationally in his own basement gym. Mens sana in corpore sano, that is, sağlam kafa, sağlam vücutta bulunur, as Mustafa Kemal Atatürk used to say. 